\title{
Skin test responsiveness to four new tuberculins in patients with chronic obstructive airways disease receiving short term high doses of, or long term maintenance treatment with, prednisolone: clinical appearances and histometric studies
}

\author{
J G LOWE,* J SWANSON BECK,* J H GIBBS,* R A BROWN, $†$ R C POTTS,* \\ J M GRANGE, $\ddagger$ J L STANFORD
}

From the Departments of ${ }^{*}$ Pathology and $\dagger$ Mathematics, University of Dundee, the $\ddagger$ Department of Microbiology, Cardiothoracic Institute, London, and the §Department of Medical Microbiology, Middlesex Hospital Medical School, London

SUMMARY The response to skin testing with tuberculins extracted from various species of mycobacteria was studied in 49 patients from Dundee with chronic obstructive airways disease. Seventeen had never been treated with steroids (group 1), 17 were receiving short term high doses of prednisolone (group 2) and did not have impaired Synacthen tests; 15 were receiving long term maintenance treatment and did have impaired Synacthen tests (group 3). Erythematous and indurated reactions were seen in a few patients, more commonly to antigens from Mycobacterium tuberculosis than to the other species: neither of the latter treatment groups showed appreciable reduction in reactivity compared with that of the group 1 patients.

The number and microanatomical distribution of the T4 and T8 lymphocytes and the M3 bearing monocytes and macrophages was studied immunocytochemically in cryostat sections of biopsy specimens from the antigen injection sites. The density of these cells was significantly less in clinically negative reactions than in those with erythema or induration, but was unrelated to the presence or absence of a history of treatment with prednisolone. The T4:T8 ratio in the section as a whole was similar to that of the peripheral blood, but $\mathrm{T} 8$ cells were relatively more common in the perivascular and periappendicular foci, and T4 lymphocytes were predominant in the diffuse component of the infiltrate. I12 receptor bearing lymphocytes were uncommon: such cells were least common in the clinically negative reactions, but the number and distribution were apparently unrelated to the presence or absence of prednisolone treatment. It was concluded that currently accepted regimens of treatment with prednisolone did not reduce the effector arm of type IV (delayed type hypersensitivity) responses and so are unlikely to compromise this aspect of protective immunity.

Glucocorticoid steroids are potent immunosuppressive drugs, yet they are often used in patients with chronic obstructive airways disease (COAD), both as long term low dosage maintenance treatment and also as short term high dose treatment during exacerbations of the disease. Surprisingly, this

Accepted for publication 8 July 1986 approach to the treatment of COAD is not usually complicated by non-respiratory intercurrent infection.

It is widely believed that treatment with glucocorticoid steroids or adrenocorticotrophic hormone (ACTH) diminishes or abolishes the characteristic 48 hour skin response in the tuberculin test and may predispose the patient to tuberculosis. In fact, neither of these assumptions is based on unequivocal evidence. Although some authors have reported that treatment 
with glucocorticoid steroids diminishes skin test reactivity, ${ }^{12}$ others have observed unchanged and even enhanced reactivity in some subjects. ${ }^{1-6}$

Citron and Scadding ${ }^{2}$ reported a suppressive effect of glucocorticoid steroids on dermal reactivity in patients with tuberculosis and noted that the degree of suppression was proportional to the reaction size before hormone treatment: those with large reactions showed considerable suppression, while there was little or no change in those with small reactions. Glucocorticoid steroids may have different effects on patients with tuberculosis from those seen in healthy subjects or patients with other diseases. Thus skin testing with a mixture of cortisone and tuberculin elicited a dermal reaction in about half of tuberculin negative patients with sarcoidosis. ${ }^{23}$

Schatz et $a l^{7}$ reported that, although high doses of glucocorticoid steroids could suppress delayed type hypersensitivity reactivity, no suppression occurred when patients with asthma received less than $15 \mathrm{mg}$ prednisolone daily, or were treated on alternate days: $28 \%$ of these patients reacted to tuberculin compared with $17-19 \%$ of the healthy controls: there was no apparent increase in the incidence of tuberculosis in the group of asthmatics on long term treatment with glucocorticoid steroids and the authors could not find clear evidence for such an increase in their search of the published reports.

Studies have so far been based on the response to tuberculin-a reagent that principally detects sensitivity resulting from prior contact with the pathogenic species Mycobacterium tuberculosis (or, in some cases, BCG). The effect of steroids on sensitisation resulting from contact with environmental mycobacteria has not been studied.

Stanford et al introduced a range of new tuberculins, which are prepared from filtered ultrasonicates of various species of mycobacteria. 89 The method of preparation avoids the antigen denaturing procedures of autolysis, heating, and protein precipitation used in the manufacture of purified protein derivative (PPD), a standard tuberculin. Accordingly, these reagents contain more of the species specific antigens than PPD and they have proved useful for detecting immunologically effective contact with both pathogenic mycobacteria and species usually occurring as environmental saprophytes. ${ }^{10}$ With a decreasing incidence of tuberculosis and the virtual absence of leprosy in Europe and other industrially developed regions, a battery of reagents prepared from environmental mycobacteria may prove more valuable in the study of recall immune reactivity than conventional tuberculins.

We now report a study of the influence of treatment with glucocorticoid steroids on the reactions of patients from Dundee with COAD to PPD and to four new tuberculins to determine the influence of current treatment regimens on skin test reactivity as a measure of effector responses in cellular immunity.

The dermal swelling in the response to tuberculin entails several different mechanisms and $w^{11}$ have shown previously that the extent of erythema and induration does not bear a direct correlation to the intensity of the inflammatory cell infiltrate within the reaction. Accordingly, histometric measurement of the intensity of the cellular infiltrate to tuberculin was undertaken to determine whether this aspect of the cell mediated response of recall immunity was impaired by the use of steroids.

\section{Material and methods}

Forty nine inpatients were studied. They had been admitted because of exacerbated respiratory failure, usually after respiratory infection, and all had given informed consent to participation in the study, which had been approved by the Dundee District Ethics Committee. Seventeen patients had never received steroids (group 1); 17 were receiving a short course of high dose prednisolone (group 2) - of these, eight had never been given steroids and nine had previously received glucocorticoid steroids for various periods, but none had impaired Synacthen tests; 15 patients had been on long term maintenance treatment and were currently being given high doses (group 3). All of the group 3 patients had impaired Synacthen tests (an increase in cortisol $<200 \mathrm{nmol} / \mathrm{l}$; peak cortisol concentration $<500 \mathrm{nmol} / \mathrm{l}$ ): two of these patients had diabetes mellitus, which in one was controlled by diet and in the other by oral drugs; none of the remaining patients in all three groups had any evidence of carbo-

Table 1 Details of patients

\begin{tabular}{|c|c|c|c|}
\hline Character & Group I & Group 2 & Group 3 \\
\hline \multicolumn{4}{|l|}{ Age range (year) } \\
\hline $\begin{array}{l}\text { Lower extreme } \\
\text { Lower quartile } \\
\text { Median } \\
\text { Upper quartile } \\
\text { Upper extreme }\end{array}$ & $\begin{array}{l}54 \\
60 \cdot 5 \\
69 \\
73 \\
79\end{array}$ & $\begin{array}{l}46 \\
61 \\
64 \\
71 \cdot 5 \\
78\end{array}$ & $\begin{array}{l}47 \\
55 \\
62 \\
68 \\
77\end{array}$ \\
\hline \multicolumn{4}{|l|}{ Sex: } \\
\hline $\begin{array}{l}\text { Men } \\
\text { Women }\end{array}$ & $\begin{array}{c}11(10) \\
6(6)\end{array}$ & $\begin{array}{l}9(7) \\
8(7)\end{array}$ & $\begin{array}{l}8(6) \\
7(7)\end{array}$ \\
\hline \multicolumn{4}{|l|}{ Recent steroid treatment: } \\
\hline $\begin{array}{l}\text { Mean daily dose (mg) } \\
\text { Duration (days) }\end{array}$ & & $\begin{array}{l}38(37) \\
13(13)\end{array}$ & $\begin{array}{l}34(34) \\
10(10)\end{array}$ \\
\hline Maintenance steroid treatment & & & $6 \cdot 3$ \\
\hline \multicolumn{4}{|c|}{ Radiological evidence of healed pulmonary tuberculosis: } \\
\hline No of patients & & 1 & 4 \\
\hline
\end{tabular}

The number of patients on whom histometric measurements were made is given in parenthesis. 
hydrate intolerance. Table 1 summarises the ages of the patients and their drug histories.

Skin tests were performed on the volar aspect of the forearms by intradermal injection of $0.1 \mathrm{ml}$ tuberculin purified protein derivative BP solution (PPD, Evans Medical Ltd, Middlesex, England) 1/1000. Similar tests were performed with four new tuberculins prepared $^{8}$ from ultrasonically disrupted $M$ tuberculosis (tuberculin), $M$ leprae (leprosin A), $M$ vaccae (vaccin) and $M$ scrofulaceum (scrofulin). The reactions were inspected after 48 hours and the extent of erythema and induration were measured with a ruler in two perpendicular diameters.

A biopsy specimen was then taken from the centre of each tuberculin injection site under local anaesthesia with $2 \%$ plain lignocaine with a $4 \mathrm{~mm}$ skin punch (Stiefel Laboratories Ltd, Slough, England). The core of tissue was bisected perpendicular to the epidermal surface: one half was fixed in $4 \%$ neutral buffered formaldehyde for resin embedded histopathological study and the other was snap frozen for immunocytochemical localisation of lymphocyte subsets and accessory cells. ${ }^{12}$ Cryostat sections $(5 \mu \mathrm{m})$ were treated with commercial monoclonal antibodies (Becton Dickinson, Sunnyvale, California, USA) to localise T4 lymphocytes (Leu 3a), T8 lymphocytes (Leu 2a), and monocyte/ macrophages (Leu M3), followed successively with the Vectastain kit containing biotinylated antimouse immunoglobulin and the third stage reagent avidinbiotinylated peroxidase (Sera lab Ltd, Crawley Down, Sussex, England), and finally, the markers were labelled with a brown reaction product by a histochemical method using diaminobenzene. Technically adequate preparations of consecutive sections stained immunocytochemically with the monoclonal antibodies to the T4, T8, and M3 antigens were obtained from 43 of the patients (table 1): the remaining six patients were not studied histometrically, because it was felt that comparison between counts of various phenotypic subpopulations in nonconsecutive sections stained at different sessions with different batches of reagents might not be valid. Because of the difficulties incurred during histometrical assessment of immunocytochemical staining by direct viewing in the microscope, monochrome photographic prints $(20 \times 16$ inches $)$ were prepared to cover the whole area of each section at a magnification of $\times 166$. The margins of the perivascular and periappendicular foci were delineated with a felt pen; the areas of these foci and of the intervening dermis were measured by cursor planimetry in a semiautomatic apparatus (Imagan Graphics Information Systems, Blairgowrie, Scotland). The numbers of cells in the phenotypic classes were then counted and their densities expressed as number $/ \mathrm{mm}^{2}$. The details of these methods have been reported previously. ${ }^{11{ }^{13}}$ Monoclonal antibody to I12 receptors (Becton Dickinson) was available to stain the last 10 specimens.

A $5 \mathrm{ml}$ venous blood sample was taken on the same day as the skin biopsy specimens for enumeration of T4 and T8 lymphocytes by flow cytofluorimetry ${ }^{14}$ with Leu 3a and Leu 2a monoclonal antibodies and polyclonal goat antimouse immunoglobulin and fluorescein isothiocyanate.

The significance of the differences in histometric counts between the various groups of patients was tested by one way analysis of variance with follow up analysis based on the Newman-Keuls procedure. ${ }^{15}$ To stabilise variances the cell density data were transformed logarithmically and the measurements of extent of focal infiltrate (proportionate data) were given an arcsin transformation. ${ }^{16}$

\section{Results}

A PPEARANCE OF SKIN TEST RESPONSE TO

TUBERCULINS PREPARED FROM FOUR

MYCOBACTERIAL SPECIES

Table 2 shows the number of patients in the three groups with indurated reactions (true positives) and those with erythematous responses. It is clear that more patients respond to tuberculin and PPD (and

Table 2 No of patients showing reaction of $>5 \mathrm{~mm}$ diameter (and mean diameter of positive reactors in $\mathrm{mm}$ )

\begin{tabular}{|c|c|c|c|c|c|}
\hline \multirow[b]{2}{*}{$\begin{array}{l}\text { Patient } \\
\text { group }\end{array}$} & \multicolumn{5}{|l|}{ Antigen } \\
\hline & $P P D$ & Tuberculin & Leprosin A & Scrofulin & Vaccin \\
\hline $\begin{array}{c}\text { Induration } \\
\text { Group 1 } \\
\text { Group 2 } \\
\text { Group 3 }\end{array}$ & $\begin{array}{l}5(29) \\
3(19) \\
3(19)\end{array}$ & $\begin{array}{l}4(24) \\
3(24) \\
2(16 \cdot 5)\end{array}$ & $\begin{array}{l}1(6) \\
0 \\
0\end{array}$ & $\begin{array}{l}2(8) \\
1(23) \\
1(15)\end{array}$ & $\begin{array}{l}3(13) \\
3(19) \\
2(14 \cdot 5)\end{array}$ \\
\hline $\begin{array}{c}\text { Erythema } \\
\text { Group 1 } \\
\text { Group 2 } \\
\text { Group 3 }\end{array}$ & $\begin{array}{l}7(27) \\
6(17 \cdot 5) \\
6(25)\end{array}$ & $\begin{array}{l}6(25) \\
6(16 \cdot 5) \\
5(18 \cdot 5)\end{array}$ & $\begin{array}{l}5(9) \\
2(12) \\
0\end{array}$ & $\begin{array}{l}6(8) \\
4(12 \cdot 5) \\
3(10)\end{array}$ & $\begin{array}{l}6(14) \\
4(16 \cdot 5) \\
4(12 \cdot 5)\end{array}$ \\
\hline
\end{tabular}


Table 3 No of antigens to which Dundee patients with COAD react

\begin{tabular}{llllll}
\hline \multirow{2}{*}{$\begin{array}{l}\text { Patient } \\
\text { group }\end{array}$} & \multicolumn{5}{l}{ No of mycobacterial antigens } \\
\cline { 2 - 6 } & 0 & $l$ & 2 & 3 & 4 \\
\hline Induration & & & & & \\
Group 1 & 10 & 5 & 0 & 2 & 0 \\
Group 2 & 14 & 0 & 2 & 1 & 0 \\
Group 3 & 10 & 3 & 2 & 0 & 0 \\
Erythema & & & & & \\
Group 1 & 9 & 2 & 0 & 2 & 4 \\
Group 2 & 9 & 3 & 2 & 1 & 2 \\
Group 3 & 8 & 3 & 2 & 2 & 0 \\
\hline
\end{tabular}

have larger reactions) than to scrofulin or leprosin $\mathrm{A}$. The responses to the panel of antigens were not significantly less common in the patients who received steroids (groups 2 and 3 ) than in patients who had not received glucocorticoid steroid drugs (group 1).

Table 3 summarises the numbers of antigens to which individual patients in the various groups react. The responses to tuberculin and PPD have been aggregated, as both antigen preparations are derived from the same mycobacterial species: the distribution of results is not materially affected when the results of the two tuberculin preparations are separated. Those patients who never received steroids seem to have reacted to a slightly wider range of antigens, but the differences were not great. Of the reactors, most showed an indurated response to only one antigen, usually that derived from $M$ tuberculosis; there was, however, much more diversity in the erythematous responses, and appreciable numbers of patients showed such reactions to three or even four antigens.

\section{HISTOMETRIC FINDINGS ON BIOPSY SPECIMENS OF TUBER CULIN IN JECTION SITES}

All of the indurated and erythematous reactions and many of the clinically negative responses to intradermal injection of tuberculin showed a chronic inflammatory reaction in the dermis: most of the inflammatory cells were concentrated as cuffs around blood vessels and skin appendages (focal infiltrate), but a substantial minority were widely distributed at low density within the intervening dermis ("diffuse" infiltrate). These appearances were closely similar to those seen in previous studies on tuberculin test sites in healthy Europeans ${ }^{13}$ and in Indonesian patients with pulmonary tuberculosis and leprosy. ${ }^{11}$

The figure shows the extent of focal infiltrate $\left(V_{v}\right.$, expressed as a percentage of the dermis), the packing density of lymphocytes in the foci (number $/ \mathrm{mm}^{2}$ ), and the density of lymphocytes in the diffuse infiltrate (number $/ \mathrm{mm}^{2}$ ) in the various groups of patients. Analysis of variance on these data (table 4) has shown that the size of the measurements on the reactions in those patients receiving prednisolone in short term high doses (with or without pituitary suppression from prior maintenance treatment) were not statistically different from the corresponding measurements on the patients who were not receiving treatment with glucocorticoid steroids. It was, however, clear that the

Table 4 Summary of analysis of variance on measurements of density of inflammatory infiltrate in dermis of tuberculin skin tests

\begin{tabular}{|c|c|c|c|c|c|c|c|}
\hline \multirow[b]{2}{*}{ Measurement } & \multirow[b]{2}{*}{ Statistic } & \multicolumn{3}{|c|}{$\begin{array}{l}\text { Comparison between steroid } \\
\text { treatment group }\end{array}$} & \multicolumn{3}{|c|}{ Clinical appearance } \\
\hline & & $l$ & 2 & 3 & Negative & Erythema & Induration \\
\hline $\begin{array}{l}\text { Focal infiltrate } \\
\text { (arcsin transformation) }\end{array}$ & $\begin{array}{l}\text { Mean } \\
\text { SE } \\
\text { No of observations } \\
\text { Variance ratio }\end{array}$ & $\begin{array}{l}0.244 \\
0.024 \\
16\end{array}$ & $\begin{array}{l}0.200 \\
0.026 \\
14 \\
1.7 \text { (NS) }\end{array}$ & $\begin{array}{l}0.179 \\
0.029 \\
13\end{array}$ & $\begin{array}{ll}0.167 & \\
0.016 & \\
27 & 10.9\end{array}$ & $\begin{array}{l}0.260 \\
0.029 \\
8 \\
<0.001)\end{array}$ & $\begin{array}{l}0.305 \\
0.029 \\
8\end{array}$ \\
\hline $\begin{array}{l}\text { Packing density in foci } \\
\text { (log transformation) }\end{array}$ & $\begin{array}{l}\text { Mean } \\
\text { SE } \\
\text { No of observations } \\
\text { Variance ratio }\end{array}$ & $\begin{array}{l}\frac{3 \cdot 55}{0 \cdot 055} \\
9\end{array}$ & $\begin{array}{c}3.51 \\
0.55 \\
9 \\
0.47 \text { (NS) }\end{array}$ & $\begin{array}{l}3.47 \\
0.55 \\
9\end{array}$ & $\begin{array}{lr}3.43 & \\
0.030 & \\
15 & \\
& 10.8\end{array}$ & $\begin{array}{l}3.68 \\
0.053 \\
5 \\
<0.001)\end{array}$ & $\begin{array}{l}3.63 \\
0.059 \\
4\end{array}$ \\
\hline $\begin{array}{l}\text { Diffuse infiltrate } \\
\text { (log transformation) }\end{array}$ & $\begin{array}{l}\text { Mean } \\
\text { SE } \\
\text { No of observations } \\
\text { Variance ratio }\end{array}$ & $\begin{array}{l}1.88 \\
0.097 \\
14\end{array}$ & $\begin{array}{c}1.79 \\
0.104 \\
14 \\
0.26 \text { (NS) }\end{array}$ & $\begin{array}{l}1 \cdot 78 \\
0 \cdot 108 \\
12\end{array}$ & $\begin{array}{ll}\begin{array}{l}1.65 \\
0.057\end{array} & \\
27 \quad 13.6\end{array}$ & $\begin{array}{l}2.09 \\
0.112 \\
7 \\
<0.001)\end{array}$ & $\begin{array}{l}2 \cdot 25 \\
0 \cdot 121 \\
6\end{array}$ \\
\hline $\begin{array}{l}\text { Monocyte/macrophage } \\
\text { density in diffuse } \\
\text { infiltrate } \\
\text { (log transformation) }\end{array}$ & $\begin{array}{l}\text { Mean } \\
\text { SE } \\
\text { No of observations } \\
\text { Variance ratio }\end{array}$ & $\begin{array}{l}\frac{1.89}{0.097} \\
15\end{array}$ & $\begin{array}{l}1.68 \\
0 \cdot 108 \\
12 \\
1.2 \text { (NS) }\end{array}$ & $\begin{array}{l}\frac{1 \cdot 74}{0 \cdot 125} \\
9\end{array}$ & $\begin{array}{ll}\begin{array}{l}1.60 \\
0.058\end{array} & \\
24 & \\
& 16.5\end{array}$ & $\begin{array}{l}2.05 \\
0.104 \\
7 \\
<0.001)\end{array}$ & $\begin{array}{l}2 \cdot 28 \\
0 \cdot 123 \\
5\end{array}$ \\
\hline
\end{tabular}

The underline denotes that the corresponding means are not significantly different $(p>0.05)$ from each other in follow up Newman-Keuls tests. 

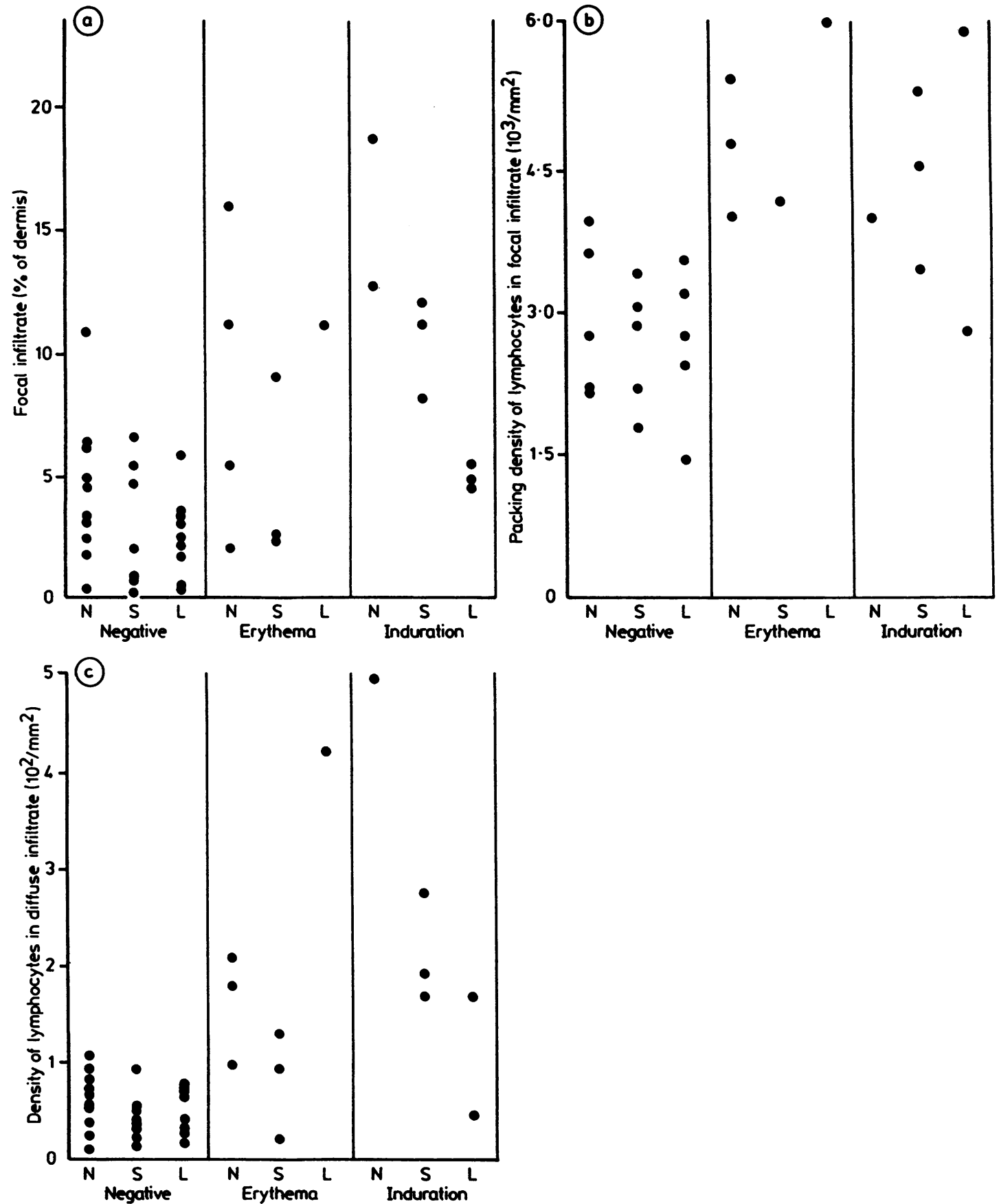

Figure Summary of histometric findings on phenotypic characters of cells in chronic inflammatory infiltrate in dermis at site of 48 hour tuberculin skin tests in patients with COAD. $N=$ no glucocorticoid steroid treatment (group 1); $S=$ short term high dose with no impairment of Synacthen tests (group 2); L = long term maintenance dose followed by bolus high dose treatment and impaired Synacthen tests (group 3). Clinical appearance is classified as negative, erythema only, and induration with erythema. (a) Extent of focal infiltrate, expressed as $\%$ of dermis; (b) packing density of lymphocytes in focal infiltrate (number $/ \mathrm{mm}^{2}$ ); (c) density of lymphocytes in diffuse component of infiltrate of dermis between foci $\left(\right.$ number $\left./ \mathrm{mm} \mathrm{m}^{2}\right)$. 
Table 5 Measurement of T4:T8 ratios

\begin{tabular}{|c|c|c|c|c|c|c|}
\hline \multirow[b]{3}{*}{ Site } & \multicolumn{6}{|c|}{ Mean (SD) T4:T8 ratios in lymphocytes at various sites in groups of patients } \\
\hline & \multicolumn{3}{|c|}{$\begin{array}{l}\text { Receiving different glucocorticoid steroid } \\
\text { treatment }\end{array}$} & \multicolumn{3}{|c|}{ Showing clinical appearance } \\
\hline & Group l & Group 2 & Group 3 & Negative & Erythema & Induration \\
\hline $\begin{array}{l}\text { No in group } \\
\text { Blood }\end{array}$ & $7.87(0.42)$ & $\begin{array}{l}9 \\
2 \cdot 13(0 \cdot 61)\end{array}$ & 7 & $12.94(0 \cdot 51)$ & $1.99(0 \cdot 28)$ & $\begin{array}{l}7 \\
1.86(0 \cdot 54)\end{array}$ \\
\hline $\begin{array}{l}\text { Skin test biopsy of: } \\
\text { Whole dermis } \\
\text { Foci } \\
\text { Diffuse }\end{array}$ & $\begin{array}{l}1.82(0.68) \\
1.27(0.34) \\
2 \cdot 16(0.55)\end{array}$ & $\begin{array}{l}2.06(0.64) \\
1.30(0.45) \\
2.27(0.55)\end{array}$ & $\begin{array}{l}2.31(1.50) \\
1.56(0.42) \\
2.61(1.11)\end{array}$ & $\begin{array}{l}2.16(0.68) \\
1.41(0.46) \\
2.70(0.77)\end{array}$ & $\begin{array}{l}1.42(0.49) \\
1.21(0.30) \\
1.88(0.37)\end{array}$ & $\begin{array}{l}2.26(1.44) \\
1.39(0.41) \\
1.98(0.60)\end{array}$ \\
\hline
\end{tabular}

extent of focal infiltrate was significantly less in those with no clinically apparent reaction to tuberculin injection than in those showing either erythema or induration, but there were no apparent differences between the clinically distinguishable grades of response.

Table 5 summarises the relative numbers of cells with the T4 and T8 markers in the peripheral blood and the various compartments of the dermal skin test reaction. Analysis of variance has shown that the differences between the T4:T8 ratios in the peripheral blood and all the cells in the sections were not significant $\left(F=0.65, V_{1}=2, V_{2}=42\right)$. The blood T4:T8 ratio was greater than that in the focal infiltrate $\left(F=7.75, V_{1}=2, V_{2}=42 ; p<0.005\right)$, but less than that in the diffuse infiltrate $\left(\mathrm{F}=3.69, \mathrm{~V}_{1}=2, \mathrm{~V}_{2}=\right.$ $42 ; p<0.05)$. The T4:T8 ratio was very much greater in the diffuse infiltrate than in the focal part $(F=$ $\left.22 \cdot 13, \mathrm{~V}_{1}=2, \mathrm{~V}_{2}=42 ; \mathrm{p}<0.001\right)$.

Ten biopsy specimens were stained with the monoclonal antibody to I12 receptors: four came from group 1 patients (two had negative reactions, one showed erythema, and the other an indurated response); three were from group 2 patients (all gave a negative reaction); and three were taken from group 3 patients (two were negative and one had an erythematous reaction). The numbers of stained cells were not measured histometrically because their distribution was patchy, clearly not distributed homogeneously, and unrelated to the microanatomical structure of the dermis. Most of the stained cells, however, were present in the focal infiltrate. The cells showing this activation marker were relatively more numerous in the erythematous and indurated reactions and were uncommon in the clinically negative reactions. The relative numbers of such $\mathrm{I} 12$ receptor bearing cells were unrelated to the history of treatment with glucocorticoid steroids.

Table 4 summarises the findings on the density of monocyte/macrophages in the diffuse infiltrate. It is clear that these measurements are quite unrelated to the history of treatment with prednisolone but are again strongly related to the clinical appearance of the reaction, being more numerous when there is erythematous or indurated response. In a further analysis it was shown that monocytes become progressively less numerous in successive layers from the upper dermis into the deeper zones $(p<0.05)$; but that this is not related to the drug treatment history $(p>0.05)$.

\section{Discussion}

The patients in group 2 had received short term high doses of prednisolone (mean $38 \mathrm{mg} /$ day), sufficient to induce immunosuppression, yet these patients did not show any appreciable reduction in the range of clinically positive skin responses to various mycobacterial antigens nor reduction in the size of these reactions of recall immunity. The patients in group 3 had also had long term maintenance treatment with prednisolone, such that there was suppression of the pituitary-adrenal axis and inhibition of endogenous adrenocortical function before the recent introduction of high dose bolus treatment for the exacerbation of COAD. Even these group 3 patients did not show appreciable reduction in the number of antigens to which they responded or in the size of the positive reactions of recall immunity to mycobacterial antigens. The patients were middle aged and elderly and had been brought up in an area where there was a high prevalence of tuberculosis when they were young. Consequently, most must have been exposed to virulent $M$ tuberculosis in earlier life. Indeed, chest $\mathrm{X}$-ray showed definitive evidence of healed pulmonary tuberculosis in seven and suggestive abnormalities in five of the $\mathbf{4 2}$ remaining subjects.

With the success of the tuberculosis eradication programme and the virtual absence of leprosy from their community, it is unlikely that the patients will have had any recent exposure to pathogenic mycobacteria and so recall immunity will be at a relatively low ebb, dependent on boosting by environmental saprophytes. ${ }^{10}$

Studies in Nepal ${ }^{17}$ and Indonesia, ${ }^{18}$ regions where both mycobacterial disease and sensitisation to 
environmental mycobacteria are common, show that subjects may be placed into three categories according to their reactivity to a set of new tuberculins. Some people react to all reagents (category 1 ), some to none (category 2), while others react to one or more but not to all reagents (category 3 ). From this it was concluded that reactors could be divided into those responding to the shared mycobacterial antigens and those responding to the species specific antigens. Furthermore, it was found that many healthy subjects were category 1 reactors, whereas those with tuberculosis or leprosy were mostly category 3 reactors. This finding implied that those with mycobacterial disease failed to recognise the shared antigens of the causative organism, but it was not clear whether this was the result of the disease or a predisposing factor. The high incidence of non-reactors (34 of 49 or $69 \%$ ) in Dundee, relative to Nepal and Indonesia, may result from a difference in the degree of contact with both pathogenic and saprophytic mycobacteria between the various populations. It is, however, rather surprising that none of the Dundee patients with COAD developed an indurated lesion to all four antigen preparations, indicating that they were not reacting to the common mycobacterial antigens. Whether this represents a basic difference in reactivity or merely reflects the differences in age distribution or environment is at present unknown. It can nevertheless be concluded that the therapeutic regimens for the treatment of exacerbations of COAD do not appreciably interfere with the visible manifestations of the effector mechanisms of delayed hypersensitivity to mycobacterial antigens derived from pathogenic and saprophytic species.

The histometric part of this investigation was designed to study the effect of treatment with glucocorticoid steroids on the patterns of cell infiltration in the dermis as part of the effector mechanisms of a type IV reaction. In the Dundee patients with COAD it has now been shown that the intensity of the lymphocyte and macrophage infiltrate is related to the clinical appearance at the injection site, but is not influenced by either low dose maintenance treatment or even by high dose bolus treatment.

Thus the present findings in man are very different from the profound suppression of mononuclear cell infiltrate seen at the site of skin tests with "old tuberculin" in rabbits treated with high doses of parenteral cortisone. ${ }^{19}$ This discrepancy can probably be explained by the fact that rabbits are sensitive to steroids, whereas man is relatively steroid resistant.$^{20}$ Since the effector mechanisms of the type IV reaction have not been modified by the tissue concentrations of prednisolone resulting from treatment, it is likely that glucocorticoid steroids exert their therapeutic action by interfering with other aspects of immunity, such as antigen recognition and processing, clonal expansion and immunoregulation, or a suppression of some other aspects of the non-specific inflammatory response. There is other evidence to indicate that inhibition of macrophage response to lymphokines occurs $^{21}$ and that the main action of the glucocorticoid steroids agents is immunoregulation rather than a change in an established response. ${ }^{22}$ Although the exact relation between tuberculin hypersensitivity and protective immunity is poorly understood and controversial, ${ }^{2324}$ it is generally accepted that a decline or loss of tuberculin reactivity is associated with many conditions that cause a weakening or failure of the host's cell mediated defence mechanisms. ${ }^{25}$ The present findings suggest strongly, therefore, that treatment with glucocorticoid steroids would not be likely to interfere with defence against tuberculosis: other explanations should therefore be eliminated before treatment with these drugs is proposed as a reason for reactivation of previously healed or cryptic tuberculosis.

It has been shown that some patients with sarcoidosis have a chronic inflammatory reaction in the dermis at the site of a clinically negative tuberculin test, ${ }^{26}$ but it was not clear whether this was a consequence of the immunological derangement of this disease or whether clinically unseen responses could occur in immunologically normal subjects with weak reactions. The present study has shown that quite substantial infiltrates can accumulate in the dermis at the site of clinically negative reactions, overlapping with clinically apparent responses, and both types of responses contain some activated lymphocytes with I12 receptors on their cell membrane. Similar positive infiltrates in clinically negative reactions were previously seen in patients with leprosy and pulmonary tuberculosis and in a few normal controls. ${ }^{11}$ As the currently accepted criteria for positivity in the tuberculin test depends on the recognition of induration of $5 \mathrm{~mm}$ or greater diameter, ${ }^{27}$ it is not clear how these cryptic infiltrates should be interpreted. Notably, Citron and Scadding ${ }^{2}$ found that local and systemic treatment abrogated the suppression of tuberculin reactivity in a high proportion of unreactive patients with sarcoidosis. This suggests that the mechanism of suppression of dermal swelling, as opposed to cellular infiltration, is sensitive to steroids. Perhaps the time is ripe for a reappraisal of the criteria for interpretation of skin tests, possibly on the basis of expression of characterised effector mechanisms.

Dr RN Johnston and Dr RA Clark kindly gave us access to their patients and discussed the experimental design with us. We are grateful to the Endowment Committee of Tayside Health Board who generously provided the flow cytofluorimeter used in this 
investigation; to Mr RS Fawkes for the preparation of the diagram; and to Mrs Rosalind Mitchell for valuable secretarial help.

\section{References}

1 Bovornkitti S, Kangsadal P, Sathirapat P, et al. Reversion and reconversion rate of tuberculin skin reactions in correlation with the use of prednisone. Dis Chest 1960;38:51-5.

2 Citron KM, Scadding JG. The effect of cortisone upon the reaction of the skin to tuberculin in tuberculosis and in sarcoidosis. QJ Med 1957;26:277-89.

3 Pyke DA, Scadding JG. Effect of cortisone upon skin sensitivity to tuberculin in sarcoidosis. $\mathrm{Br}$ Med J 1952;ii:1126-8.

4 Truelove LH. Enhancement of Mantoux reaction coincident with treatment with cortisone and prednisolone. $\mathrm{Br} \mathrm{Med} \mathrm{J}$ 1957;ii:1135-7.

5 Fairley GH, Matthias JQ. Cortisone and skin sensitivity to tuberculin in reticuloses. $\mathrm{Br}$ Med J 1960;ii:433-6.

6 MacGregor RR, Sheagren JN, Lipsett MB, et al. Alternative day prednisone therapy. Evaluation of delayed hypersensitivity responses, control of disease and steroid side effects. $N$ Engl $J$ Med 1969;280:1427-31.

7 Schatz M, Patterson R, Kloner R, et al. The prevalence of tuberculosis and positive skin tests in a steroid-treated asthmatic population. Ann Intern Med 1976;84:261-5.

8 Stanford JL, Revill WDL, Gunthorpe WJ, et al. The production and preliminary investigation of Burulin, a new skin test reagent for Mycobacterium ulcerans infection. J Hyg (Camb) 1975;74:7-16.

9 Shield MJ, Stanford JL, Paul RC, et al. Multiple skin testing of tuberculosis patients with a range of new tuberculins and a comparison with leprosy and Mycobacteria ulcerans infection. J Hyg (Camb) 1977;78:331-48.

10 Shield MJ. The importance of immunologically effective contact with environmental mycobacteria. In: Ratledge C, Stanford JL, eds. The biology of the mycobacteria. Vol. 2. New York: Academic Press, 1983:343-415.

11 Beck JS, Morley SM, Gibbs JH, et al. The cellular responses of tuberculosis and leprosy patients and of healthy controls in skin tests to "New Tuberculin" and Leprosin A. Clin Exp Immunol 1986;64:484-94.

12 Coghill G, Gibbs JH, Lowe JG, et al. Cryopreservation with glycerol during cryostat sectioning for localisation of lymphocytes and accessory cell phenotypic subsets in tissue biopsies. J Clin Pathol 1985;38:840-2.
13 Gibbs JH, Ferguson J, Brown RA, et al. Histometric study of the localisation of lymphocyte subsets and accessory cells in human Mantoux reactions. J Clin Pathol 1984;37:1227-34.

14 Roberts C, Potts RC, Brown RA, et al. The sensitivity of peripheral blood lymphocytes to growth inhibition by hydrocortisone is not determined by their OKT4:OKT8 ratio. Immunol Lett 1983;6:227-30.

15 Miller RG. Simultaneous statistical inference. New York: McGraw Hill Book Company, 1966:82-4.

16 Armitage P. Statistical methods in medical research. Oxford: Blackwell Scientific Publications, 1971:355-7.

17 Stanford JL, Nye PM, Rook GA, et al. A preliminary investigation of the responsiveness or otherwise of patients and staff of a leprosy hospital to groups of shared or species specific antigens of mycobacteria. Lepr Rev 1981;52:321-7.

18 Kardjito T, Beck JS, Grange JM, et al. A comparison of the responsiveness to four new tuberculins among Indonesian patients with pulmonary tuberculosis and healthy subjects. Eur J Respir Dis (in press).

19 Gell PGH, Hinde IT. The histology of the tuberculin reaction and its modification by cortisone. Br J Exp Pathol 1952;32:516-29.

20 Claman HN. Corticosteroids and lymphoid cells. $N$ Engl J Med 1972;287:388-97.

21 Fauci AS. Mechanisms of the immunosuppressive and antiinflammatory effects of glucosteroids. J Immunopharmacol 1978-9;1:1-25.

22 Cupps TR, Fauci AS. Corticosteroid-mediated immunoregulation in man. Immunol Rev 1982;65:133-55.

23 Youmans PH. Tuberculosis. Philadelphia: WP Saunders Co, 1984:302-16.

24 Lagrange PH. Cell mediated immunity and delayed-type hypersensitivity. In: Kubica GP, Wayne LW, eds. The mycobacteria: a source book Part B. New York: Mercel Dekker, 1984:681-720.

25 Caplin M. The tuberculin test in clinical practice: an illustrative guide. London: Baillière Tindal, 1980:72.

26 Mishra BB, Poulter LW, Janossy G, et al. The distribution of lymphoid and macrophage-like cell subsets of sarcoid and Kveim granulomata: possible mechanism of negative PPD reaction in sarcoidosis. Clin Exp Immunol 1983;54:705-15.

27 Sokol JE. Measurement of delayed skin-test responses. $N$ Engl J Med 1975;293:501-2.

Requests for reprints to: Professor J Swanson Beck, Department of Pathology, Ninewells Hospital and Medical School, PO Box 120, Dundee DD1 9SY, Scotland. 